\title{
Effect of Dietary Phytase on Protein and Electrolyte Utilization on Broiler Chicks Production
}

\author{
Sami Ahmed Mohamed Arabi \\ Academic Affairs, University of Al Fashir, P.O. Box 125-AlFashir, North Darfur State, Sudan
}

\begin{abstract}
The objective of this study was to determine the effect of dietary supplementation of Phytase (Ronozyme ${ }^{\circledR}$ ) FYT/U ( 0 and 750 ) added with 19.5 and $23 \%$ Crude protein and ( $0.45 \%$ ) available phosphorus (aP) to the diet. 1-d-old Ross 308 chicks (144) were reared in litter floor pens and fed 42 days. The chicks were randomly divided into six treatments eight groups of 6 chicks. Diets were formulated with and without commercial microbial phytase, body weight and feed intake were measured weekly to assess growth response. Test groups (the $750 \mathrm{FYT} / \mathrm{U} / \mathrm{kg}$ diets) mean values for daily feed intake higher significantly than the control (97.87 vs. 86.30). All tibia bone measurements for the $750 \mathrm{FYT} / \mathrm{U} / \mathrm{kg}$ diets were higher compared to the control. Total $\mathrm{P}$ and $\mathrm{Ca}$ consumptions and total $\mathrm{P}$ and $\mathrm{Ca}$ retentions\% for the $750 \mathrm{FYT} / \mathrm{U} / \mathrm{kg}$ diets were higher significantly compared to the control Profitability ratios of the test groups (750 FYT/U) were always higher than the control group. Results of the present study suggest that the addition of dietary phytase was found to increase the phosphorous phytate utilization and similarly reduce the phosphorous loss in the excreta.
\end{abstract}

Key words: Dietary phytase, phosphorous, Ca retentions, tibia bone, profitability ratios

Science International, $1(2): 15-21,2013$

\section{INTRODUCTION}

The beneficial effect of enzymes in the cereal diets is based on the hydrolysis of the viscous nonstarch polysaccharides. Korengay ${ }^{1}$ reported that $735 \mathrm{U}$ of phytase/kg diet was equivalent to $1 \mathrm{~g}$ of nonphytate $\mathrm{P}$ for broilers fed corn-soybean meal diets, and that about 20 to $60 \%$ of phytate $\mathrm{P}$ was hydrolyzed by graded levels of supplemental phytase. Mamduh ${ }^{2}$ founded that feed enzymes hold great promise to impact positively on the feed industry if managed in accordance with environmental parameters. Shmasaeli ${ }^{3}$ documented that the addition of the enzyme had no positive effect on weight gain, but it decreased the feed intake significantly $(\mathrm{p}<0.05)^{4,5}$ feed enzymes improve nutrient digestibility and hence promote better growth rate and FCE in chickens. Ledoux ${ }^{6}$ reported that phytase improved feed intake and body weight gains of turkey hens grown to Market age. Punna and Roland ${ }^{7}$ reported that ability to retain phytate phosphorus varied significantly among individual birds of the same strain of broilers. The objective of the experiment was to determine the addition of commercial microbial phytase (Ronozyme ${ }^{\circledR}$ ) were tested enhance the growth performance in broiler chicken.

MATERIAL AND METHODS

Experimental chicks: A total number of 144 day-old commercial unsexed broiler chicks of Ross 308 strain were purchased from The Arab Company for Livestock Development -Khartoum, and transported to the Student Poultry Premises, Faculty of Agricultural Studies, Sudan University of Sciences and Technology, Shambat. All chicks were weighed with an average initial weight of $45 \mathrm{~g}$ day old chick. The chicks were then allotted randomly to 8 groups, each of six replicates of six chicks each. Ground brooding/rearing system was adopted for the six weeks experimental periods. Each pen was equipped with one feeder and drinker to allow ad libitum consumption of feed and water Chicks were bought vaccinated against Marek's, Newcastle and Gambaro, soluble multi-vitamin compounds (Pantominovit-Pantex Holland B.V. 5525 ZG DuizelHolland) were given during the first 3 days of age and for 4 days before and after vaccination to guard against stress.

Housing: Open wire mesh-side poultry house was used. The house was constructed on a concrete floor, with a corrugated metal sheet roof and a solid brick WesternEaster wall up to 3 meters the eaves and 4-5 $\mathrm{m}$ for apex. Six pens, $1.5 \mathrm{~m}^{2}$ each, inside the house, were prepared using wire mesh partitioning, light was provided approximately $14 \mathrm{~h} /$ day allowing one hour before sunset and one after dawn. Four bulbs (60 watt) lamps were used for this purpose. 
Experimental rations: A basal diet was formulated to yield 23 and $19.5 \% \mathrm{CP}$ and $3000 \mathrm{kcal} \mathrm{ME} / \mathrm{kg}$ being adequate in all nutrients except for $\mathrm{nPP}$ and calcium, aP $(0.45 \%)$ and $\mathrm{Ca}(1.84)$ and (1.46) according to Suleiman ${ }^{8}$. Table 1 Ration ingredients were sorghum, sesame cake, groundnut cake, and wheat bran microbial phytase 0,750 FYT/U were added to the basal diet. Experimental diets were fed for 42 days.

Performance data: Average body weights, weight gain and feed consumption (g) for each group were determined weekly throughout the experimental period, Meanwhile, health of the experimental stock and mortality were closely observed.

Serum analyses: Serum was analyzed for concentration of total protein, cholesterol, lipids, and triglyceride AOAC (1988).

Slaughter procedure and carcass data: At the end of the 6th week the birds were fasted overnight with water

Table 1: The percentage and calculated analysis of experimental diets

\begin{tabular}{llllll}
\hline \multicolumn{5}{c}{ Composition of } & \\
Ingredients & \multicolumn{3}{l}{ basal diets (\%) } & Composition of diets \\
\hline Fetarita & 60.46 & 64 & Crude protein (\%) & 23 & 19.50 \\
Ground nut cake & 14.46 & 9.77 & Ether extract (\%) & 3.5 & 3.4 \\
Sesame cake & 14.80 & 9.51 & Crude fiber (\%) & 11.80 & 11.20 \\
Bone meal & 02.11 & 1.972 & Ash(\%) & 4.20 & 4.40 \\
Wheat brand & 00.50 & 6.66 & M E, Kcal/Kg & 3000 & 3000 \\
Salt(NCl) & 02.67 & 0.25 & Total P (\%) & 0.678 & 0.88 \\
Concentrate & 05.00 & 05.00 & a phosphorous (\%) & 045 & 0.45 \\
Oyster flour & - & 3.84 & Calcium (\%) & 1.84 & 1.46 \\
Vitamin* \& min. & 0.02 & 0.02 & Crude protein (\%) & 23 & 19.50 \\
Ronozyme & + & + & & & \\
Lysine & - & 0.025 & & & \\
Total & 100 & 100 & & & \\
\hline
\end{tabular}

*Guaranteed levels of vitamin and minerals supplements per kg product: vit. A: $300.000 \mathrm{UI}$; vit. D3: $100.00 \mathrm{UI}$; vit. $4.00 \mathrm{mg}$; vit K: $98 \mathrm{mg}$; vit. B2: $1.320 \mathrm{MG}$; vit. B12: $4.000 \mathrm{mg}$; pantothenate: $2.000 \mathrm{mg}$; niacin: $20.000 \mathrm{mg}$; folic acid: $100 \mathrm{mg}$; choline: $50.000 \mathrm{mg}$; copper: $15.000 \mathrm{mg}$; iodine: $250 \mathrm{mg}$; selenium: $50 \mathrm{mg}$; manganese: $24.000 \mathrm{mg}$; zinc: $20.000 \mathrm{mg}$; iron: 10.000 mg; coccide: $25.000 \mathrm{mg}$; antioxidant; $125 \mathrm{mg}$ and vehicle q.s.p: $1.000 \mathrm{~g}$ allowed slaughtered terminally. Birds were weighed individually before slaughter by severing the right and left carotid and jugular vessels, trachea and esophagus. After bleeding they were scaled in hot water, handplucked and washed. The head was removed close to skull; feet and shanks were removed at the hock joint. Evisceration was accomplished by a posterior ventral cut to completely remove the visceral organs. Hot carcass and each have the Intestines, liver, and gizzard were separately weighted. Carcass was chilled in refrigerator at $4 \mathrm{C}^{\circ}$ for $24 \mathrm{~h}$ before further preparation.

Chemical analyses: The experimental diets, bone, manure and meat samples were proximately analyzed according to AOAC (1988).

Phosphate determination: Procedure was run following Mehta ${ }^{9}$.

The taste panel: Following recommended the procedure according to Hawrysh ${ }^{10}$.

Statistical analysis: Statistical examination of the data was performed using the analysis of variance using Least Significant Difference (LSD) procedures of SAS ${ }^{11}$ was used to separate significant differences refer to the $5 \%$ level of probability. Data was analyzed as described in published references. A $2 \times 2 \times 2$ factorial arrangements of treatment in the main plot with pen as the experimental unit. Specific differences between treatment means were determined using Duncan's multiple range tests.

\section{RESULTS AND DISCUSSION}

Performance value of broiler chicks: The effect of feeding dietary microbial phytase on performance of broiler chicks is shown in Table 2 . Initially all groups started at similar ( $p>0.05)$ body weight. Treatment effect in all performance entities was significant $(\mathrm{p}>0.05)$ mean values for initial weight, body weight gain and final

Table 2: Analysis of variance and average (Mean $\pm \mathrm{SD}$ ) performance values of broiler chicks fed high levels of phytase and nonphytate Phosphorous (nPP) with different levels of Crude Protein 19.5 and $23 \%$ CP for 42 days

\begin{tabular}{|c|c|c|c|c|}
\hline \multirow[b]{4}{*}{ Items } & \multicolumn{4}{|c|}{$0.45 \%$ available Phosphorous (nP) } \\
\hline & \multicolumn{4}{|l|}{$\mathrm{CP}$} \\
\hline & \multicolumn{2}{|l|}{$23 \%$} & \multicolumn{2}{|l|}{$19.5 \%$} \\
\hline & 0 & 750 & 0 & 750 \\
\hline Initial weight & $45.00 \pm 0.00$ & $45.00 \pm 0.00$ & $45.00 \pm 0.00$ & $45.00 \pm 0.00$ \\
\hline Final weight & $1881.10 \pm 92.36^{\mathrm{a}}$ & $1988.86 \pm 92.36^{\mathrm{a}}$ & $1834.20 \pm 92.53^{\mathrm{a}}$ & $1801.89 \pm 92.53^{\mathrm{a}}$ \\
\hline Weight gain & $1839.10 \pm 92.53^{\mathrm{a}}$ & $1946.90 \pm 92.53^{\mathrm{a}}$ & $1879.20 \pm 92.36^{\mathrm{a}}$ & $1846.89 \pm 92.36^{\mathrm{a}}$ \\
\hline Daily feed intake (g) & $86.30 \pm 0.24^{\mathrm{b}}$ & $97.87 \pm 0.21^{\mathrm{a}}$ & $103.37 \pm 0.24^{\mathrm{a}}$ & $80.00 \pm 0.21^{\mathrm{b}}$ \\
\hline Daily D.M. intake (g) & $81.12 \pm 0.81^{\mathrm{b}}$ & $92.00 \pm 0.65^{\mathrm{a}}$ & $97.17 \pm 0.81^{\mathrm{a}}$ & $75.20 \pm 0.56^{\mathrm{b}}$ \\
\hline Daily energy intake (g) & $74.63 \pm 0.20^{\mathrm{b}}$ & $84.64 \pm 0.21^{\mathrm{a}}$ & $89.40 \pm 0.20^{2}$ & $69.18 \pm 0.21^{\mathrm{b}}$ \\
\hline Feed conversion ratio & $2.73 \pm 0.51^{\mathrm{a}}$ & $01.97 \pm 00.51^{\mathrm{b}}$ & $2.31 \pm 0.51^{2}$ & $1.82 \pm 0.51^{\mathrm{b}}$ \\
\hline
\end{tabular}

Means within the same columns with different superscript are significantly $(\mathrm{p}<0.05)$ different 
Table 3: Analysis of variance and average (Mean $\pm \mathrm{SD}$ ) serum metabolites values of broiler chicks of broiler chicks fed high levels of phytase and nonphytate Phosphorous (nPP) with different levels of Crude Protein 19.5 and $23 \%$ CP for 42 days

\begin{tabular}{|c|c|c|c|c|}
\hline & \multicolumn{4}{|c|}{$0.45 \%$ available Phosphorous $(\mathrm{nP})$} \\
\hline & \multicolumn{4}{|l|}{$\mathrm{CP}$} \\
\hline & \multicolumn{2}{|l|}{$23 \%$} & \multicolumn{2}{|l|}{$19.5 \%$} \\
\hline Items & 0 & 750 & 0 & 750 \\
\hline Total protein (g\%) & $7.30 \pm 0.82^{\mathrm{a}}$ & $7.50 \pm 0.82^{\mathrm{a}}$ & $7.20 \pm 0.82^{\mathrm{a}}$ & $7.90 \pm 0.82^{\mathrm{a}}$ \\
\hline Cholesterol (mg \%) & $125.00 \pm 21.35^{\mathrm{a}}$ & $120.00 \pm 21.35^{\mathrm{b}}$ & $133.00 \pm 0.82^{\mathrm{b}}$ & $145.00 \pm 0.82^{\mathrm{a}}$ \\
\hline Triglyceride (mg \%) & $106.00 \pm 0.088^{\mathrm{a}}$ & $105.00 \pm 0.088^{\mathrm{b}}$ & $101.50 \pm 0.82^{\mathrm{b}}$ & $107.20 \pm 0.82^{\mathrm{a}}$ \\
\hline Lipids (mg \%) & $7.60 \pm 0.65^{\mathrm{a}}$ & $7.50 \pm 0.65^{\mathrm{b}}$ & $7.47 \pm 0.82^{\mathrm{a}}$ & $7.65 \pm 0.82^{a}$ \\
\hline
\end{tabular}

Means within the same columns with different superscript are significantly $(\mathrm{p}<0.05)$ different

weight was similar $(\mathrm{p}>0.05)$. This results were agreed by Lazaro $^{12}$ concluded that enzyme supplementation added to rye diets decreased intestinal viscosity and accelerated digestive transit, improving productive performance of broilers also Zhang ${ }^{13}$ investigated that it can be inferred that direct selection for phytate phosphorus bioavailability can consequently led to concurrent changes in BW, BWG, FC, and FCR. Onyango ${ }^{14}$ reported that the evolved phytase efficacious in improving broiler growth performance, bone characteristics, and retention of $\mathrm{P}, \mathrm{Ca}, \mathrm{N}$, and a number of amino acids. Wang ${ }^{15}$ reported that exogenous enzymes (primarily xylanase and â-glucanase) can improve performance of broilers consuming a wheat-based diet, especially during the growing period. Test group daily feed intake, daily dry matter intake, daily energy intake and feed conversion ratio mean values were lower $(\mathrm{p}<0.05)$ than the control values. According to El-Husseiny ${ }^{16}$ phytase supplementation to low- nPP diets improved broiler performance.

Leeson and Proulx ${ }^{17}$ showed that commercial enzyme preparations tested increased the ME of high $\beta$ glucan barley; Abdulilah ${ }^{18}$ indicated that the performance of the bird was altered by the addition of enzyme. ${ }^{7}$ The dietary phytase treatment effect in differences in growth, livability. According to Zanella ${ }^{19}$ the supplementation of the diets with an enzyme mixture improved the digestibility of the nutrients and broiler performance allowed a reduction in the energy formulation of the diets. Steve ${ }^{5}$ estimated that broiler chickens fed wheatbased diets respond well to phytase, especially in early growth rate and improved carcass characteristics. Ravindran ${ }^{20}$ reported that supplemental graded levels of phytase (125 to $1,000 \mathrm{U} / \mathrm{kg})$ significantly improved growth performance of chicks fed a lysine-deficient diet containing wheat, sorghum, soybean meal, canola meal, rice polishing, and corn gluten meal. Gracia ${ }^{21}$ suggested that heat processing and enzyme supplementation increased apparent retention of nutrients, $\mathrm{AME}_{\mathrm{n}}$ of the diet. Jang ${ }^{22}$ showed that an improvement in growth is due to increased available $\mathrm{P}$ when using the low phytate grains over the wild-type grains. The result of $\mathrm{Islam}^{23}$ revealed that the enzyme levels had a significant effect $(p<0.001)$ on live weight at the age of 42 days (marketing age).

Serum metabolites: The change in the concentrations of serum metabolites of broiler chicks is shown in Table 3 . The dietary phytase treatment effect in all serum metabolites was significant $(\mathrm{p}<0.05)$. Mean values in total protein, cholesterol and lipids of treatment groups were similar $(p>0.05)$ except for the triglycerides $(p<0.05)$. Edney ${ }^{24}$ reported that improved digestibility of lipids, carbohydrates and protein results in an increase in the apparent metabolizable energy of the ingredient. Supplementation level increased (equivalent to $750 \mathrm{U}$ or $1,000 \mathrm{U}$ phytase/kg of feed), the plasma $\mathrm{P}$ concentrations increased to levels that were significantly greater than that obtained with the normal-NPP $\operatorname{diet}^{25}$. El-Husseiny ${ }^{16}$ reorted that phytase supplementation to low- nPP diets improved increased plasma $\mathrm{p}$ level $(\mathrm{p}<0.01)$.

Slaughter and Carcass data: The results obtained for the slaughter and carcass measurements were exposed in Table 4 . The treatment effect was significant $(\mathrm{p}<0.05)$ in all carcass and slaughter parameters except for liver and heart percentages. The mean slaughter weight of the test group was significantly $(\mathrm{p}<0.05)$ different from the control. Shmasaeli ${ }^{3}$ suggested that enzyme significantly improved FCR. Test group mean values in remaining parameters were higher $(\mathrm{p}>0.05)$ than the control except for the breast and total edible parts percent $(\mathrm{p}>0.05)$. The very low $\mathrm{Ca}$ and $\mathrm{P}$ levels in the deficient diets $(0.60 \% \mathrm{Ca}$, $0.47 \% \mathrm{tP} ; 0.30 \% \mathrm{Ca}, 0.37 \%$ tP to optimize BWG and FCR when supplemented with phytase ${ }^{26}$. Gracia ${ }^{21}$ concluded that broiler performance is improved by enzyme supplementation of the diet.

Bone quality: Results of tibia bone qualities were seen in Table 5. The treatment effect was significant $(\mathrm{p}<0.05)$ in all tibia values. Applegate ${ }^{27}$ dietary NPP formulations can be substantially reduced from industry averages without negatively affecting bird performance or bone mineralization at $49 \mathrm{~d}$ of age. Punna and Roland ${ }^{7}$ 
Table 4: Analysis of variance and average (Mean \pm SD) slaughter and carcass values of broiler chicks fed high levels of phytase and nonphytate Phosphorous (nPP) with different levels of Crude Protein 19.5 and $23 \%$ CP for 42 days

\begin{tabular}{|c|c|c|c|c|}
\hline \multirow[b]{4}{*}{ Items } & \multicolumn{4}{|c|}{$0.45 \%$ available Phosphorous(nP) } \\
\hline & \multicolumn{4}{|l|}{$\mathrm{CP}$} \\
\hline & \multicolumn{2}{|l|}{$23 \%$} & \multicolumn{2}{|l|}{$19.5 \%$} \\
\hline & 0 & 750 & 0 & 750 \\
\hline Slaughter weight & $1881.10 \pm 6.80^{\mathrm{b}}$ & $1988.86 \pm 6.8^{\mathrm{a}}$ & $1888.89 \pm 7.1^{\mathrm{b}}$ & $1922.20 \pm 7.09^{\mathrm{a}}$ \\
\hline Hot carcass wt. & $1316.77 \pm 148.6^{\mathrm{a}}$ & $1414.47 \pm 148.6^{\mathrm{a}}$ & $1346.37 \pm 72.6^{\mathrm{a}}$ & $1370.22 \pm 72.63^{\mathrm{a}}$ \\
\hline Cold carcass wt. & $1328.77 \pm 121.3^{\mathrm{a}}$ & $1427.47 \pm 121.3^{\mathrm{a}}$ & $1333.37 \pm 51.04^{\mathrm{a}}$ & $1358.22 \pm 51.04^{\mathrm{a}}$ \\
\hline Shrinkage (\%) & $0.36 \pm 0.4^{\mathrm{a}}$ & $0.35 \pm 0.1^{\mathrm{a}}$ & $0.59 \pm 0.04^{\mathrm{a}}$ & $0.32 \pm 0.01^{\mathrm{b}}$ \\
\hline Hot dressing (\%) & $69.00 \pm 6.80^{\mathrm{a}}$ & $69.12 \pm 6.80^{\mathrm{a}}$ & $69.66 \pm 6.80^{\mathrm{a}}$ & $69.59 \pm 6.80^{\mathrm{a}}$ \\
\hline Cold dressing $(\%)$ & $68.64 \pm 6.80^{\mathrm{a}}$ & $68.77 \pm 6.80^{\mathrm{a}}$ & $68.87 \pm 6.80^{\mathrm{a}}$ & $69.28 \pm 6.80^{\mathrm{a}}$ \\
\hline Liver $(\%)$ & $3.22 \pm 6.80^{a}$ & $3.25 \pm 6.80^{\mathrm{a}}$ & $2.78 \pm 0.13^{a}$ & $3.00 \pm 0.13^{\mathrm{a}}$ \\
\hline Heart $(\%)$ & $0.45 \pm .086^{a}$ & $0.46 \pm 0.086^{\mathrm{a}}$ & $0.28 \pm 0.13^{a}$ & $0.26 \pm 0.13^{\mathrm{a}}$ \\
\hline Gizzard (\%) & $3.70 \pm .086^{\mathrm{a}}$ & $3.75 \pm 0.086^{\mathrm{a}}$ & $3.28 \pm 0.13^{\mathrm{a}}$ & $3.50 \pm 0.13^{\mathrm{a}}$ \\
\hline Breast & $41.60 \pm 6.80^{\mathrm{a}}$ & $40.86 \pm 6.80^{\mathrm{a}}$ & $21.528 \pm 6.80^{\mathrm{b}}$ & $40.17 \pm 6.80^{\mathrm{a}}$ \\
\hline Thigh (\%) & $31.55 \pm 7.086^{\mathrm{a}}$ & $31.30 \pm 7.086^{\mathrm{a}}$ & $29.52 \pm 0.13^{\mathrm{a}}$ & $29.48 \pm 0.13^{\mathrm{a}}$ \\
\hline Total edible part (\%) & $79.22 \pm 7.09^{\mathrm{a}}$ & $78.62 \pm 7.086^{\mathrm{a}}$ & $74.67 \pm 7.461^{\mathrm{a}}$ & $75.03 \pm 7.461^{\mathrm{a}}$ \\
\hline
\end{tabular}

Means within the same columns with different superscript are significantly $(\mathrm{p}<0.05)$ different

Table 5: Analysis of variance and average (Mean \pm SD) tibia values of broiler chicks fed high levels of phytase and nonphytate Phosphorous (nPP) with different levels of Crude Protein 19.5 and $23 \%$ CP for 42 days

\begin{tabular}{|c|c|c|c|c|}
\hline & \multicolumn{4}{|c|}{$0.45 \%$ available Phosphorous $(\mathrm{nP})$} \\
\hline & \multicolumn{4}{|l|}{$\mathrm{CP}$} \\
\hline & \multicolumn{2}{|l|}{$23 \%$} & \multicolumn{2}{|l|}{$19.5 \%$} \\
\hline Items & 0 & 750 & 0 & 750 \\
\hline Tibia length $(\mathrm{Tl}) \mathrm{cm}$ & $7.00 \pm 0.08^{b}$ & $7.31 \pm 0.08^{\mathrm{a}}$ & $6.83 \pm 1.89^{\mathrm{a}}$ & $6.84 \pm 1.89^{a}$ \\
\hline Tibia width (TW) $\mathrm{cm}$ & $0.57 \pm 0.09^{\mathrm{a}}$ & $0.63 \pm 0.09^{\mathrm{a}}$ & $0.512 \pm 0.65^{\mathrm{a}}$ & $0.53 \pm 0.65^{\mathrm{a}}$ \\
\hline Tibia breaking strength (TBS) kg & $23.70 \pm 0.65^{\mathrm{b}}$ & $29.80 \pm 0.65^{\mathrm{a}}$ & $30.02 \pm 1.89^{\mathrm{a}}$ & $30.01 \pm 1.89^{\mathrm{a}}$ \\
\hline
\end{tabular}

Means within the same columns with different superscript are significantly $(\mathrm{p}<0.05)$ different

Table 6: Analysis of variance and average (Mean \pm SD) tibia mineral values of broiler chicks fed high levels of phytase and nonphytate Phosphorous (nPP) with different levels of Crude Protein 19.5 and $23 \%$ CP for 42 days

\begin{tabular}{|c|c|c|c|c|}
\hline \multirow[b]{4}{*}{ Items } & \multicolumn{4}{|c|}{$0.45 \%$ available Phosphorous $(\mathrm{nP})$} \\
\hline & \multicolumn{4}{|l|}{$\mathrm{CP}$} \\
\hline & \multicolumn{2}{|l|}{$23 \%$} & \multicolumn{2}{|l|}{$19.5 \%$} \\
\hline & 0 & 750 & 0 & 750 \\
\hline$\overline{\text { Dry matter }}$ & $92.60 \pm 0.65^{b}$ & $94.97 \pm 0.65^{a}$ & $94.10 \pm 1.90^{a}$ & $95.21 \pm 1.90^{2}$ \\
\hline Phosphorous & $0.50 \pm 0.08^{\mathrm{a}}$ & $0.46 \pm 0.08^{\mathrm{a}}$ & $0.63 \pm 0.08^{\mathrm{a}}$ & $0.60 \pm 0.08^{a}$ \\
\hline Sodium & $1.64 \pm 0.08^{\mathrm{a}}$ & $1.53 \pm 0.08^{\mathrm{b}}$ & $1.56 \pm 0.08^{\mathrm{a}}$ & $1.61 \pm 0.08^{\mathrm{a}}$ \\
\hline Calcium & $13.13 \pm 1.90^{\mathrm{a}}$ & $13.07 \pm 1.90^{\mathrm{b}}$ & $13.20 \pm 0.67^{\mathrm{a}}$ & $12.63 \pm 0.67^{\mathrm{a}}$ \\
\hline Ash & $48.58 \pm 0.65^{a}$ & $48.80 \pm 0.65^{\mathrm{b}}$ & $46.30 \pm 1.90^{\mathrm{a}}$ & $46.60 \pm 1.90^{\mathrm{a}}$ \\
\hline
\end{tabular}

Means within the same columns with different superscript are significantly $(\mathrm{p}<0.05)$ different

investigated that bone quality among individual birds were related to the variation in phytate phosphorus retention. ${ }^{22}$ Correlations among the percentage bone ash, total bone ash, and bone strength indicated a strong relation and appear to support the use of bone strength analysis Test mean value for tibia bone length and tibia bone breaking strength was higher $(p>0.05)$ than the control. Mean value for tibia width was similar $(p>0.05)$ to the control. Skinner ${ }^{28}$ documented that tibia strength was significantly $(\mathrm{p}=0.001)$ affected by dietary treatment. Within each NPP level, tibia strength increased as $\mathrm{Ca}$ level of the diet increased. An improvement bone performance was observed due to increased available $\mathrm{P}$ when using the low phytate grains over the wild-type grains ${ }^{22}$.

Tibia chemical analyses: The results of tibia chemical analysis were cited in Table 6 . Treatment effect in all tibia chemical analyses was significant $(p<0.05)$. Test mean values for tibia phosphorous, sodium, calcium and ash, were similar $(p>0.05)$ to the control. The test group mean value in dry matter was higher $(\mathrm{p}<0.05)$ than the 
Table 7: Analysis of variance and average (Mean $\pm \mathrm{SD}$ ) phosphorus availability of broiler chicks fed high levels of phytase and nonphytate Phosphorous (nPP) with different levels of Crude Protein 19.5 and $23 \% \mathrm{CP}$ for 42 days

\begin{tabular}{|c|c|c|c|c|}
\hline & \multicolumn{4}{|c|}{$0.45 \%$ available Phosphorous $(\mathrm{nP})$} \\
\hline & \multicolumn{4}{|l|}{$\mathrm{CP}$} \\
\hline & \multicolumn{2}{|l|}{$23 \%$} & \multicolumn{2}{|l|}{$19.5 \%$} \\
\hline Items & 0 & 750 & 0 & 750 \\
\hline Total feed consumption (g) & $4110.60 \pm 56.86^{a}$ & $3624.40 \pm 51.05^{\mathrm{b}}$ & $4341.67 \pm 0.05^{\mathrm{a}}$ & $3360.00 \pm 56.86^{\mathrm{b}}$ \\
\hline Total P consumption (mg) & $3193.01 \pm 85.44^{\mathrm{b}}$ & $3621.44 \pm 85.44^{\mathrm{a}}$ & $3825.01 \pm 39.1^{\mathrm{a}}$ & $2960.16 \pm 4.41^{\mathrm{b}}$ \\
\hline Total manure excreted (g) & $1087.32 \pm 10.69^{\mathrm{b}}$ & $1223.18 \pm 15.37^{\mathrm{a}}$ & $1302.50 \pm 10.69^{\mathrm{a}}$ & $1008.00 \pm 15.70^{\mathrm{b}}$ \\
\hline Total P excreted (mg) & $645.64 \pm 186.67^{a}$ & $611.59 \pm 186.67^{\mathrm{a}}$ & $795.99 \pm 43.43^{\mathrm{a}}$ & $556.81 \pm 4.61^{\mathrm{b}}$ \\
\hline Total $P$ retained (mg) & $2547.45 \pm 108.69^{\mathrm{b}}$ & $3009.85 \pm 108.69^{\mathrm{a}}$ & $3029.03 \pm 108.70^{\mathrm{a}}$ & $2403.34 \pm 108.70^{\mathrm{b}}$ \\
\hline Total $\mathrm{P}$ retention $(\%)$ & $79.78 \pm 0.82^{\mathrm{b}}$ & $83.11 \pm 0.82^{\mathrm{a}}$ & $79.19 \pm 0.31^{\mathrm{b}}$ & $81.19 \pm 0.44^{\mathrm{a}}$ \\
\hline \multicolumn{5}{|c|}{ Means within the same columns with different superscript are significantly $(\mathrm{p}<0.05)$ different } \\
\hline \multicolumn{5}{|c|}{$\begin{array}{l}\text { Table 8: Analysis of variance and average (mean } \pm \text { st.dev) Calcium availability of broiler chicks fed high levels of phytase and nonphytate Phosphorous (nPP) } \\
\text { with different levels of Crude Protein } 19.5 \text { and } 23 \% \text { CP for } 42 \text { days }\end{array}$} \\
\hline & \multicolumn{4}{|c|}{$0.45 \%$ available Phosphorous $(\mathrm{nP})$} \\
\hline & \multicolumn{4}{|l|}{$\mathrm{CP}$} \\
\hline & \multicolumn{2}{|l|}{$23 \%$} & \multicolumn{2}{|l|}{$19.5 \%$} \\
\hline Items & 0 & 750 & 0 & 750 \\
\hline Total feed consumption (g) & $4110.60 \pm 56.86^{a}$ & $3624.40 \pm 0.05^{\mathrm{b}}$ & $4341.67 \pm 0.05^{\mathrm{a}}$ & $3360.00 \pm 56.86^{\mathrm{b}}$ \\
\hline Total Ca consumption (mg) & $6668.89 \pm 123.4^{\mathrm{b}}$ & $7563.504 \pm 123.40^{\mathrm{a}}$ & $6338.84 \pm 45.7^{\mathrm{a}}$ & $4905.60 \pm 27.9^{\mathrm{b}}$ \\
\hline Total manure excreted (g) & $1087.32 \pm 153.49^{\mathrm{a}}$ & $1223.18 \pm 153.49^{\mathrm{a}}$ & $1302.50 \pm 10.69^{a}$ & $1008.00 \pm 10.69^{\mathrm{b}}$ \\
\hline Total Ca excreted (mg) & $1768.59 \pm 343.83^{\mathrm{a}}$ & $1598.17 \pm 343.83^{\mathrm{a}}$ & $1255.72 \pm 8.16^{\mathrm{a}}$ & $853.59 \pm 6.82^{\mathrm{b}}$ \\
\hline Total Ca retained (mg) & $4900.31 \pm 565.24^{a}$ & $5965.34 \pm 565.24^{a}$ & $5083.12 \pm 0.86^{\mathrm{a}}$ & $4052.01 \pm 0.47^{\mathrm{b}}$ \\
\hline Total Ca retention (\%) & $73.48 \pm 0.86^{\mathrm{b}}$ & $78.87 \pm 0.47^{\mathrm{a}}$ & $80.19 \pm 0.86^{\mathrm{b}}$ & $82.60 \pm 0.47^{a}$ \\
\hline
\end{tabular}

Means within the same columns with different superscript are significantly $(\mathrm{p}<0.05)$ different

control group. According to Korengay ${ }^{1}$ graded levels of phytase increased $\mathrm{Ca}$ and $\mathrm{P}$ retention by up to 18 and $14 \%$, respectively, for 66 and $660 \mathrm{mg}$ of $\mathrm{D} 3 / \mathrm{kg}$ diet. That increased utilization of phytate $\mathrm{Ca}$ and $\mathrm{P}$ results in increased $\mathrm{Ca}$ and $\mathrm{P}$ retention is also supported by our findings of an increase in $\mathrm{Ca}, \mathrm{P}, \mathrm{Zn}$, and $\mathrm{Mg}$ in bone ash and improved bone calcification and histological development. El-Husseiny ${ }^{16}$ dcumented that phytase supplementation to low- nPP diets improved tibia weight and mineral retention.

Minerals balance: The mineral phosphorous availability is shown in Table 7. Effect in all phosphorous availability measurements was significant $(\mathrm{p}<0.05)$. Test mean values for $\mathrm{P}$ consumptions, total manure excreted, total $\mathrm{P}$ retained and total $\mathrm{P}$ retention \% values were higher $(\mathrm{p}>0.05)$ than the control. Test group mean value for total $\mathrm{P}$ excreted was similar $(\mathrm{p}>0.05)$ in value compared to the control. Test means value for feed consumptions was lower $(\mathrm{p}<0.05)$ compared to the control. Shirley and dwards ${ }^{29}$ suggested that higher levels of phytase can be used to improve the overall utilization of phytate $\mathrm{P}$ and possibly other nutrients in a $\mathrm{tP}$-deficient diet. Viveros ${ }^{30}$ demonstrated that microbial phytase supplementation to low-P diets improved performance; $\mathrm{P}, \mathrm{Ca}, \mathrm{Mg}$, and $\mathrm{Zn}$ use; and tibia weight and relative liver weight in broiler chickens. Lan $^{25}$ supplementation of phytase increased $(\mathrm{p}<0.05)$ the AME value, digestibility of $\mathrm{DM}$ and $\mathrm{CP}$, and retention of $\mathrm{P}, \mathrm{Ca}$, and $\mathrm{Cu}$. $\mathrm{Mn}$ retention in broilers was only increased $(p<0.05)$ by phytase supplementation from 18 to $20 \mathrm{~d}$ of age, and $\mathrm{Zn}$ retention was improved $(\mathrm{p}<0.05)$ only at a high level of $1,000 \mathrm{U}$ phytase $/ \mathrm{kg}$ of feed supplementation.

Calcium availability: The mineral calcium availability is cited in Table 8. Driver ${ }^{31}$ observed that the true value of phytase is a complex function of dietary $\mathrm{Ca}$, total and phytate $\mathrm{P}$ concentrations, and the cost of $\mathrm{Ca}$ and $\mathrm{P}$ supplementation. Treatment effect in all calcium availability measurements was significant $(\mathrm{p}<0.05)$. Test group mean values of total $\mathrm{Ca}$ consumption and total $\mathrm{Ca}$ retention\% were higher $(\mathrm{p}<0.05)$ in value compared to the control. Test group means values for total manure excreted, total $\mathrm{Ca}$ excreted and total $\mathrm{Ca}$ retention was similar $(p>0.05)$. Test means value for total feed consumptions was lower $(\mathrm{p}<0.05)$ compared to the control. ${ }^{7}$ available phosphorus in the diet significantly influenced the level of phytate phosphorus retention. In turkey hens grown to market age, partial substitution of phytase for a $\mathrm{P}$ did not result in increased $\mathrm{P}$ retention from commercial corn-soybean meal diets. Yan $^{32}$ suggested that phytase supplementation should allow for 
Table 9: Major inputs and margin over major inputs (per head) of broiler chicks fed high levels of phytase and nonphytate Phosphorous (nPP) with different levels of Crude Protein 19.5 and $23 \% \mathrm{CP}$ for 42 days

\begin{tabular}{|c|c|c|c|c|}
\hline \multirow[b]{4}{*}{ Item } & \multicolumn{4}{|c|}{$0.45 \%$ available Phosphorous(nPP) } \\
\hline & \multicolumn{4}{|l|}{$\mathrm{CP}$} \\
\hline & \multicolumn{2}{|l|}{$23 \%$} & \multicolumn{2}{|l|}{$19.5 \%$} \\
\hline & 0 & 750 & 0 & 750 \\
\hline$\overline{\text { Meat sales (SDD) }}{ }^{*}$ & 1227.272 & 1292.759 & 1192.23 & 1171.183 \\
\hline Chick purchase (SDD) & 185.00 & 185.00 & 185.00 & 185.00 \\
\hline Feed $\cos (\mathrm{SDD})^{* *}$ & 180.85 & 159.46 & 177.502 & 137.368 \\
\hline Major cost of production & 515.85 & 494.46 & 512.502 & 472.368 \\
\hline Margin over major inputs & 711.422 & 798.299 & 679.728 & 698.815 \\
\hline Profitability & 57.97 & 61.75 & 57.013 & 59.67 \\
\hline Profitability ratio & 1.00 & 1.065 & 1.000 & 1.048 \\
\hline
\end{tabular}

markedly reduced excretion of phosphorus in the litter with no reduction in live performance or in bone development. El-Husseiny ${ }^{16}$ phytase supplementation to low-nPP diets improved decreased plasma $(\mathrm{P}<0.01) \mathrm{Ca}$, $\mathrm{Zn}$, and Mg levels.

Economy profile: Major inputs and margin over inputs (SDG) of different dietary treatments of broiler chicks were shown in Table 9. Chick purchase and Feed cost values (SDG) were the major inputs considered and margin over inputs (SDG) of different dietary treatments of broiler. The total selling values of meat is the total income obtained. Profitability ratio (1.065 and 1.048) of the test group (750 FYT/) was higher than the control group. Economicwise, the addition of phytase could make reasonable profits than without its addition. The profitability element here is based on feed, as it constitutes more than $60 \%$ of the ration cost for poultry feeding. Further benefits lie within the improvement of digestibilities and consequent by better utilization of nutrients. ${ }^{23}$ net profits (kg live bird) was significantly better in broiler group fed diet supplemented with enzyme $50 \mathrm{~g} / 100 \mathrm{~kg}$. It was assumed always that in this and similar studies, purchases of stock are equal and good if management is similarly run. El-Husseiny ${ }^{16}$ phytase supplementation to low- nPP diets improved nutrients digestibility coefficients, economic efficiency.Margin differences only lies in gains achieved. In intensive and large scale poultry production, minor inputs and good management always proved critical.

\section{REFERANCES}

1. Korengay, E.T., D.M. Denbow, Z. Yi and V. Ravindran, 1996. Response of broilers to graded levels of microbial phytase added to maize-soybean meal-based diets containing three levels of nonphytate phosphorus. Br. J. Nutr., 75: 839-852.

2. Sifri, M., 1993. Enzymes in poultry feeds: What are the facts? Proceedings of the Informal Nutrition Confererrce, (IN'93) Des Moines, Iowa.
3. Shmasaeli, S.H., M. Mayahi and A. Rasekh, 2010. A comparison between the effects of probiotic and enzyme on the performance of broiler chicks. Indian J. Anim. Sci., 80: 913-915.

4. Bedford, M.R., 1993. Mode of action of feed enzymes. J. Applied Poult. Res., 2: 85-92.

5. Leeson, S., L.J. Caston and D. Yungblut, 1996. Adding roxazyme to wheat diets of chicken and turkey broilers. J. Applied Poult. Res., 5: 167-172.

6. Ledoux, D.R., K. Zyla and T.L. Veum, 1995. Substitution of phytase for inorganic phosphorus for turkey hens. J. Applied Poult. Res., 4: 157-163.

7. Punna, S. and D.A. Ronald, 1999. Variations in the phytate phosphorus utilization within the same broiler strain. J. Appl. Poult. Res., 8: 10-15.

8. Sulieman, Y.R. and A. Abd-Ra-Mabrouk, 1999. The Nutrient Composition of Sudanese Animal Feeds (Bulletin III). Animal Production Research Centre Publications, Khartoum North, Sudan.

9. Mehta, N.C., J.O. Legg, C.A.I. Goring and C.A. Black, 1954. Determination of organic phosphorus in soils: I. Extraction method. Soil Sci. Soc. Am., 18: 443-449.

10. Haweysh, Z.J., C.D. Steedman-Douglas, A.R. Robblee, R.T. Hardin and R.M. Sam, 1980. Influence of low glucosinolate rapeseed meal on the eating quality of broiler chickens1subjective evaluation by trained taste panel and objective measurements. Poult. Sci., 59: 550-557.

11. SAS, 1988. SAS Users Guide: Statistics Release 6.04.. SAS Institute Inc., Cary, New Jersey, USA.

12. Lazaro, R., M. Garcia, P. Medel and G.G. Mateos, 2003. Influence of enzymes on performance and digestive parameters of broilers fed rye-based diets. Poult. Sci., 82: 132-140.

13. Zhang, W., S.E. Aggrey, G.M. Pesti, R.I. Bakalli and H.M. Jr. Edwards, 2005. Correlated responses to divergent selection for phytate phosphorus bioavailability in a randombred chicken population. Poult. Sci., 84: 536-542. 
14. Onyango, E.M., M.R. Bedford and O. Adeola, 2005. Efficacy of an evolved Escherichia coli phytase in diets of broiler chicks. Poult. Sci., 84: 248-255.

15. Wang, Z.R., S.Y. Oiao, W.O. Lu and D.F. Li, 2005. Effects of enzyme supplementation on performance nutrient digestibility gastrointestinal morphology and volatile fatty acid profiles in the hindgut of broilers fed wheat-based diets. Poult. Sci., 84: 875-881.

16. El-Husseiny, O.M., S. Abou El-Wafa and M. Shabaan, 2006. Influence of dietary phytase on broiler performance fed low phosphorous corn/soybean or sunflower diets base on digestibility or deficient amino acids. Egypt. Poultry Sci. J., 26: 427-454.

17. Leeson, S. and J. Proulx, 1994. Enzymes and barley metabolizable energy. J. Appl. Poultry Res., 3: 66-68.

18. Mohammed, A.H., 1995. Barley varieties enzyme supplementation and broiler performance. J. Applied Poult. Res., 4: 230-234.

19. Zanella, I., N.K. Sakomura, F.G. Silversides, A. Fiqueirdo and M. Pack, 1999. Effects of enzyme supplementation of broiler diets based on corn and soyabeans. Poult. Sci., 78: 561-568.

20. Ravindran, V., P.H. Selle, G. Ravindran, P.C.H. Morel, A.K. Kies and W.L. Bryden, 2001. Microbial phytase improves performance, apparent metabolizable energy and ileal amino acid digestibility of broilers fed a lysine-deficient diet. Poult. Sci., 80: 338-344.

21. Garcia, M.I., M.A. Latorre, M. Garcia, R. Lazaro and G.G. Mateos, 2003. Heat processing of barley and enzyme supplementation of diet for broilers. Poult. Sci., 82: 1281-1291.

22. Jang, D.A., J.G. Fadel, K.C. Klasing, A.J. Mireles Jr. and R.A. Ernst et al., 2003. Evaluation of low-phytate corn and barley on broiler chick performance. Poult. Sci., 82: 1914-1924.

23. Islam, S.S., P. Akter, J.R. Pal, P. Gain and M.K.A. Khan, 2010. Effect of different levels of exogenous enzyme supplementation to the diet on broiler performances. Indian J. Anim. Sci., 80: $479-480$.
24. Edney, M.J., G.L. Campbell and H.L. Classen, 1989. The effect of â-glucanase supplementation on nutrient digestibility and growth in broilers given diets containing carley, oat groats or wheat. Anim. Feed Sci. Tech., 25: 193-200.

25. Lan, G.Q., N. Abdullah, S. Jalaludin and Y.W. Ho, 2002. Efficacy of supplementation of a phytaseproducing bacterial culture on the performance and nutrient use of broiler chickens fed corn-soybean meal diets. Poult. Sci., 81: 1522-1532.

26. Driver, J.P., G.M. Pesti, R.I. Bakalli and H.M. Jr. Edwards, 2005. Phytase and 1alphahydroxycholecalciferol supplementation of broiler chickens during the starting and growing/finishing phases. Poult. Sci., 84: 1616-1628.

27. Applegate, T.J., B.C. Joern, D.L. Nussbaum-Wagler and R. Angel, 2003. Water soluble phosphorus in fresh broiler litter is dependent upon phosphorus concentration fed but not on fungal phytase supplementation. Poult. Sci., 82: 1024-1029.

28. Skinner, J.T., M.H. Adams, S.E. Watkins and P.W.W. Waldroup, 1992. Effect of calcium and nonphytate phosphorous levels fed during 42-56 days of age on performance and bone strength of male broilers. J. Applied Poultry Res., 1: 167-171.

29. Shirley, R.B. and H.M. Jr. Edwards, 2003. Graded levels of phytase past industry standards improves broiler performance. Poult. Sci., 82: 671-680.

30. Viveros, A., A. Brenes, I. Arija and C. Centeno, 2002. Effects of microbial phytase supplementation on mineral utilization and serum enzyme activities in broiler chicks fed different levels of phosphorus. Poult. Sci., 81: 1172-1183.

31. Driver, J.P., G.M. Pesti, R.I. Bakalli and H.M. Edwards, 2005. Effects of calcium and nonphytate phosphorus concentrations on phytase efficacy in broiler chicks. Poult. Sci., 84: 1406-1417.

32. Yan, F., J.H. Kersey, C.A. Fritts and P.W. Waldrup, 2003. Phosphorus requirements of broiler chicks 3-6 weeks of age as influenced by phytase supplementation. Poult. Sci., 82: 294-300. 